\title{
The effect of railroads and price responsiveness on acreage decisions in the post-Bellum period
}

\section{Ebru Guven Solakoglu}

To cite this article: Ebru Guven Solakoglu (2008) The effect of railroads and price responsiveness on acreage decisions in the post-Bellum period, Applied Economics, 40:6, 765-771, DOI:

$10.1080 / 00036840600749599$

To link to this article: http://dx.doi.org/10.1080/00036840600749599

\section{1.}

\section{Submit your article to this journal $\sqrt{3}$}

Џ Article views: 29

Q View related articles $\sqsubset$

4 Citing articles: 1 View citing articles ๘ 


\title{
The effect of railroads and price responsiveness on acreage decisions in the post-Bellum period
}

\author{
Ebru Guven Solakoglu \\ Department of Banking and Finance, Bilkent University, Turkey \\ E-mail:egsolakoglu@fatih.edu.tr
}

\begin{abstract}
This study analyses the effect of farmers' price responsiveness and railroad development on acreage decisions in the late 19th century. A potential simultaneity between these determinants was mentioned in some earlier studies, but never examined. This study sheds some light on these relationships by employing a simultaneous equations model. The results show that acreage, prices and railroad mileage were jointly determined in the late nineteenth century. Furthermore, farmers were very responsive to wheat prices in their wheat acreage decisions in the eastern and northeastern regions when endogeneity effect is considered. In the western and southern regions, however, farmers were not responsive to wheat prices in their wheat acreage decisions. On the other hand, they were very responsive to corn and animal prices in their corn acreage decisions. Railroads were one important determinant that affected farmers' acreage decisions positively in every region.
\end{abstract}

\section{Introduction}

President Jefferson's purchase of the Louisiana Territory in 1803, followed by the Florida Acquisition in 1819, almost doubled the size of the country. After subsequent purchases, the country completed the territory that comprises the first 48 states. ${ }^{1}$ The federal government held 1.2 million acres in 1850s and started taking important steps with settlement laws and land grants to railroads. These actions preceded actual settlement and cultivation. The land grant system transferred usable land in the western region of the country to private ownership. Wheat became the most valuable and easily transported grain product as production of staple farm products moved to the West. Shipments from the Midwest towards the northern, eastern and southern states grew over $10 \%$ annually, while the population of the region grew at over 5\% annually.

The US government chartered the Union Pacific in 1862, and initiated land grants for railroads to make the land system more effective. As railroads developed transportation costs decreased through the end of the century, production costs decreased and this motivated the early mid-western farmers to produce for the market. Markets became better integrated through regional trade, thus wheat prices decreased in the consuming regions and rose in frontier producing areas and relative prices decreased (Guven Solakoglu and Goodwin, 2005). In response to higher production prices, the frontier expanded. And when it reached its limits, regions started to specialize in producing a specific crop-mix.

${ }^{1}$ Texas annexation occurred in 1845, Oregon county annexation occurred in 1846, Mexican acquisition occurred in 1848. For detailed information see Atack and Passell (1994). 
Expecting to find significant effects of grain prices on farmer's cultivation decisions in the nineteenth century, many early studies investigated the relationship between the share of acreage planted and relative prices. Some studies found no relationship between these variables (Malenbaum, 1953; Fisher and Temin, 1970; Cooley and DeCanio, 1977), where some others found such relationship (Harley, 1978). Harley (1978) claimed that the reason for the failure of the previous studies to find such relationship was because there was no attention to spatial distribution of prices in these studies. He also drew attention to the potential simultaneity between wheat production, prices and railroads. However, he ignored the case suggesting simultaneity would be small since the data contains individual states, and most of the railroads were built by 1880 s. Thus, none of these studies explicitly considered the possibility of simultaneity between these variables when investigating such relationship. Yet, according to Fishlow 'a key issue, however, is whether such railroad influence was primarily exogenous or endogenous, whether railroads first set in motion the forces culminating in the economic development of the decade, or whether arising in response to profitable situations, they played a more passive role'. (1965, p. 203).

If Fishlow's statement is correct, then we should test for a possible simultaneity between changes in wheat acreage and changes in wheat prices with railroad development. Therefore, this study argues that railroad mileage, acreage and prices of wheat may be jointly determined and follows an investigation similar to Harley's (1978), with similar time period but with different considerations. ${ }^{2}$ Specifically, we investigate the effects of wheat prices and railroad development on total acreage of wheat in 43 states of the United States for an unbalanced period between 1866 and 1906, taking the simultaneity problem into account.

The remainder of this article is organized as follows. We first develop two models that investigate the relationships between the amount of wheat acreage, wheat prices, corn prices and railroad development, and describe the estimation techniques. After employing the models for five regions of the United States and the country as a whole, we also briefly investigate the price responsiveness of western farmers and analyse their decisions to cultivate corn regarding their response to corn and livestock prices and railroad development. Finally, we conclude the study.

\section{Data, Models and Estimation Methods}

Our primary data set is an unbalanced panel of annual observations on total acreage, production and prices of wheat and corn for 43 states from 1866 to 1906, obtained from the U.S. Department of Agriculture, Bureau of Statistics. ${ }^{3}$ The data for railroad mileage for each state is obtained from two data sources. The first set comes from Manuals of Railroads of the United States by Henry Poor. It covers the period from 1866 to 1887 . The second data set covers the years from 1888 to 1906 , and it is obtained from Statistics of Railways, Interstate Commerce Commission. ${ }^{4}$

The first model asserts that cultivated area for wheat depends on the price of wheat, railroad mileage and the previous year's acreage amount for wheat.

$$
\log A_{i t}^{\mathrm{W}}=\alpha+\beta \log P_{i t}^{\mathrm{W}}+\mu \log A_{i t-1}^{\mathrm{W}}+\rho \operatorname{LogRR}{ }_{i t}+\varepsilon_{i t}
$$

where $A^{\mathrm{w}}$ denotes the amount of acreage for wheat, $t$ denotes year, $i$ denotes the region, $P^{\mathrm{w}}$ is the price of wheat, RR is the railroad mileage, and $\varepsilon_{i}$ is the error term. We assume that farmers based their decisions on current price, not on expected price. Thus, at higher prices, the amount of acreage increases as farmers move to less accessible areas. This is not an unreasonable assumption for the examined period, since farmers were specialized in grain crops. Therefore, although expected and actual prices were

\footnotetext{
${ }^{2}$ This study incorporates Harley's (1978) argument on the importance of spatial distribution of prices altered in the years between 1850 and 1913 and includes individual states into the analysis. However, the time span appears to be slightly shorter than Harley's.

${ }^{3}$ Bulletin 56 and 57 were issued on 1907 and 1908 including data on wheat crops and corn crops, respectively, in the United States from 1866 to 1907. Region 1 includes the northeastern states: Maine, New Hampshire, Vermont, Massachusetts, Rhode Island and Connecticut. Region 2 includes the eastern states: New York, Pennsylvania, Ohio, Michigan, Indiana, Maryland, Delaware, New Jersey, and District of Columbia. Region 3 includes the southern states: Virginia, Kentucky, Tennessee, Mississippi, Alabama, Georgia, Florida, North Carolina and South Carolina. Region 4 includes the mid-western states: Illinois, Iowa, Wisconsin, Missouri and Minnesota. Region 5 includes the far-western states: Arkansas, North and South Dakota, Oklahoma, New Mexico, Wyoming, Montana, Idaho, Utah, Arizona, Washington, Nebraska, Kansas, Texas, Colorado, California, Nevada and Oregon. We excluded Rhode Island, Connecticut, Florida, Louisiana, and Wyoming since they presented scattered data. The remaining data set contained 1446 observations.

${ }^{4}$ This first annual report is issued in 30 June 1888, Washington.
} 
not equal, the adjustment process to expected price was very rapid (Bogue, 1963).

In the second specification, we include corn prices as a determinant in the model as it is an important source of agricultural income in some regions during this period.

$$
\begin{aligned}
\log A_{i t}^{\mathrm{w}}= & \alpha+\beta \log P_{i t}^{\mathrm{w}}+\gamma \log P_{i t}^{\mathrm{c}}+\mu \log A_{i t-1}^{\mathrm{w}} \\
& +\rho \operatorname{LogRR} R_{i t}+\varepsilon_{i t}
\end{aligned}
$$

In Equation 2, $A^{\mathrm{w}}$ stands for acreage of wheat, $t$ denotes year and $i$ denotes the region. $P^{\mathrm{w}}$ and $P^{\mathrm{c}}$ are the prices of wheat and corn, respectively, RR is the railroad mileage, and $\varepsilon_{i}$ is the error term. We expect farmers to favour corn to cultivate at higher prices for corn, and hence the amount of acreage planted in wheat will decrease. ${ }^{5}$ During the examined period, the production decisions changed in terms of less wheat and less corn production in many Eastern States, while both corn and wheat production increased in the West. The reason for that trend was not only the price changes, but also mechanization, which decreased the costs of preparation in flat western lands. On the other hand, the acreage of both corn and wheat increased in the far western region. In many states of the southern and western regions, production decisions favoured corn production.

We test every single regressor in the model individually and their combinations by using Hausman's single-equation $F$-test, and see whether they indicate endogeneity together. Suppose there is a positive correlation between a regressor and the error term. When the disturbance is higher the dependent variable is higher, and counting for the correlation between the regressor and the error term, the regressor is likely to be higher. Thus, estimating the relationship with ordinary least squares (OLS) will overestimate the slope of the true relationship, and the OLS estimates will be inconsistent. Endogeneity test can be performed by running the following regression: $Y=X \beta+W \theta+\varepsilon$. In this equation, $W$ refers to a set of instruments for explanatory variable(s) $X$, and $Y$ is the endogenous variable. Then we test the null hypothesis that $\theta$ is equal to zero with an $F$-test. Rejecting the null hypothesis indicates endogeneity. If endogeneity exists, then we estimate the model by the 2SLS method to obtain consistent estimates. ${ }^{6}$

\section{Empirical Results and Discussions}

Empirical results for simultaneity for the country as a whole and the five regions of the United States are presented in Table 1. According to the F-tests, the price of wheat, individually and with other variables, suggests the presence of endogeneity in the model at $1 \%$ significance level for the whole country and all regions except the Midwest. In the midwest, endogeneity problem appears for corn prices according to the $F$-test results. Therefore, we treat all right-hand-side variables, except $A_{t-1}$, in Equations 1 and 2 as endogenous, chose instrumental variables and estimate the model by the 2SLS method to obtain consistent estimates. ${ }^{7}$ These results are presented in Table 2.

Both, the first and the second models for the United States reject the hypothesis of no simultaneity at $1 \%$ significance level. According to OLS estimates in the first model, wheat prices are significant in explaining the change in acreage of wheat at $10 \%$ significance level. The coefficient of railroad development, however, is statistically insignificant. On the other hand, when we model prices and railroad mileage endogenously, their impact on the change in wheat acreage is large. According to 2SLS estimates, both the price of wheat and railroad development lead to a positive change in wheat acreage at $1 \%$ significance level.

We get similar results from 2SLS estimates when we add corn prices into the model. In the second model, OLS gives very small estimates for wheat and corn prices and railroad mileage. However, when we model wheat acreage, wheat and corn prices and railroad mileage simultaneously, we see that both the price of wheat and railroad mileage increases the acreage decisions in favour of wheat cultivation, and their effect is large. Corn prices influence the change in acreage for wheat negatively at $10 \%$ significance level.

\footnotetext{
${ }^{5}$ Harley (1978) argued that animal prices were more appropriate variables than corn prices, although corn was the largest crop in many mid-western states, because it was an intermediate input into meat production. However, this study also focuses on how acreage decisions change in favour of corn for many states. We expect to see decreases in the acreage amount of wheat at higher prices of corn or animals. Therefore, using corn prices or animal prices should give similar effects on acreage amounts.

${ }^{6}$ Kennedy (1992) suggests two problems with the Wu-Hausman test. First, he argues that $\left[V\left(\beta^{\mathrm{IV}}\right)-V\left(\beta^{\mathrm{OLS}}\right)\right]$ cannot be inverted in the normal ways, and second, the estimated $\left[V\left(\beta^{\mathrm{IV}}\right)-V\left(\beta^{\mathrm{OLS}}\right)\right]$ may have incorrect signs against what theory says. Therefore, he suggests Hausman's second test, which is not different from the Wald test. It is computationally attractive, though.

${ }^{7}$ We used lagged endogenous variables as instruments in our model.
} 
Table 1. F-test results for simultaneity

\begin{tabular}{|c|c|c|c|c|c|c|}
\hline \multicolumn{7}{|c|}{ Dependent variable: $\ln A_{t}^{\mathrm{w}}$} \\
\hline & $\begin{array}{l}\text { Full } \\
\text { sample }\end{array}$ & $\begin{array}{l}\text { Region } 1 \\
\text { (Northeast) }\end{array}$ & $\begin{array}{l}\text { Region } 2 \\
\text { (East) }\end{array}$ & $\begin{array}{l}\text { Region } 3 \\
\text { (South) }\end{array}$ & $\begin{array}{l}\text { Region } 4 \\
\text { (Midwest) }\end{array}$ & $\begin{array}{l}\text { Region } 5 \\
\text { (Farwest) }\end{array}$ \\
\hline \multicolumn{7}{|l|}{$\begin{array}{l}\text { Model 1: } \\
\text { RR }\end{array}$} \\
\hline$P^{\mathrm{W}}$ & $* *$ & $*$ & $* *$ & $*$ & & $*$ \\
\hline $\mathrm{RR}, P^{\mathrm{w}}$ & $* *$ & $* *$ & $* *$ & & & \\
\hline \multicolumn{7}{|l|}{ Model 2: } \\
\hline $\begin{array}{l}P^{\mathrm{c}} \\
\mathrm{RR}, P^{\mathrm{c}}\end{array}$ & & & & & * & \\
\hline$P^{\mathrm{c}}, P^{\mathrm{w}}$ & $* *$ & $*$ & $* *$ & * & * & $*$ \\
\hline $\mathrm{RR}, P^{\mathrm{c}}, P^{\mathrm{w}}$ & $* *$ & $*$ & $* *$ & * & * & \\
\hline
\end{tabular}

Notes: ${ }^{*},{ }^{* *}$ Denote significance levels at 5 and $1 \%$ levels, respectively.

$P^{\mathrm{w}}$ and $P^{\mathrm{c}}$ state for wheat and corn prices, respectively; RR stands for railroad mileage.

Table 2. Simultaneity corrected results

\begin{tabular}{|c|c|c|c|c|c|c|c|}
\hline & & Constant & $P^{\text {wheat }}$ & RR & $A_{t-1}^{\mathrm{w}}$ & $P^{\text {corn }}$ & Wald \\
\hline \multicolumn{8}{|l|}{$\overline{\ln A_{t}^{\mathrm{w}}}$} \\
\hline & US & & & & & & \\
\hline \multirow[t]{2}{*}{ Model 1} & OLS & $0.01268^{*}$ & $0.0584^{*}$ & 0.0083 & $0.8692 * * *$ & & $25.11 * * *$ \\
\hline & 2SLS & 0.0107 & $0.3476 * * *$ & $0.0829 * * *$ & 0.8519 & & \\
\hline \multirow[t]{3}{*}{ Model 2} & OLS & 0.0103 & 0.0363 & 0.0052 & $0.8724 * * *$ & 0.0398 & $33.39 * * *$ \\
\hline & 2SLS & 0.0088 & $0.4703 * * *$ & $0.0853 * * *$ & $0.8577 * * *$ & $-0.1518^{*}$ & \\
\hline & Region 1 & & & & & & \\
\hline \multirow[t]{2}{*}{ Model 1} & OLS & -0.0459 & $0.4988 * *$ & -0.1131 & $0.8253 * * *$ & & $9.76 * *$ \\
\hline & $2 \mathrm{SLS}$ & -0.0138 & $1.6482 * * *$ & $0.5263 *$ & $0.7549 * * *$ & & \\
\hline \multirow[t]{3}{*}{ Model 2} & OLS & $-0.0582^{*}$ & 0.3180 & 0.0543 & $0.7987 * * *$ & $0.5086^{* *}$ & $7.62 *$ \\
\hline & 2SLS & -0.0321 & $1.2495 * *$ & $0.5890^{*}$ & $0.7428 * * *$ & 0.5155 & \\
\hline & Region 2 & & & & & & \\
\hline \multirow[t]{2}{*}{ Model 1} & OLS & 0.0029 & -0.0362 & 0.0127 & $0.7649 * * *$ & & $10.61 * *$ \\
\hline & 2SLS & 0.0044 & $0.1944 * *$ & $0.1392 * * *$ & $0.7608 * * *$ & & \\
\hline \multirow[t]{3}{*}{ Model 2} & OLS & 0.0028 & -0.0458 & 0.0198 & $0.7600 * * *$ & 0.0384 & $10.30 * *$ \\
\hline & 2SLS & 0.0047 & $0.2289 * *$ & $0.1422 * * *$ & $0.7668 * * *$ & -0.0492 & \\
\hline & Region 3 & & & & & & \\
\hline \multirow[t]{2}{*}{ Model 1} & OLS & -0.0021 & -0.0264 & -0.0662 & $0.8852 * * *$ & & 4.26 \\
\hline & $2 \mathrm{SLS}$ & 0.0007 & $0.3306^{*}$ & 0.0553 & $0.8735^{* * *}$ & & \\
\hline \multirow[t]{3}{*}{ Model 2} & OLS & -0.0020 & -0.0392 & -0.0671 & 0.8840 *** & 0.0266 & 6.16 \\
\hline & 2SLS & 0.0018 & $0.6920 * *$ & 0.1249 & $0.8877 * * *$ & -0.4071 & \\
\hline & Region 4 & & & & & & \\
\hline \multirow[t]{2}{*}{ Model 1} & OLS & 0.0134 & -0.0253 & $-0.0806 * * *$ & $0.9025 * * *$ & & 1.84 \\
\hline & 2SLS & 0.0139 & 0.2332 & -0.0353 & $0.8784 * * *$ & & \\
\hline \multirow[t]{3}{*}{ Model 2} & OLS & 0.0133 & -0.0236 & $-0.0814^{* * *}$ & $0.9023 * * *$ & -0.0107 & 5.97 \\
\hline & 2SLS & 0.0136 & $0.3643 *$ & -0.0349 & $0.8648 * * *$ & -0.2048 & \\
\hline & Region 5 & & & & & & \\
\hline \multirow[t]{2}{*}{ Model 1} & OLS & $0.0406^{* * *}$ & -0.0490 & $0.0664 * *$ & $0.7924 * * *$ & & 4.84 \\
\hline & 2SLS & $0.0283 *$ & $0.2701 *$ & $0.1223 * * *$ & $0.7911 * * *$ & & \\
\hline \multirow[t]{2}{*}{ Model 2} & OLS & $0.0406^{* * *}$ & -0.0394 & $0.0657 * *$ & $0.7925^{* * *}$ & -0.0222 & 5.49 \\
\hline & 2SLS & $0.0288^{*}$ & $0.4637 * *$ & $0.1129 * * *$ & $0.7938 * * *$ & -0.3610 & \\
\hline
\end{tabular}

Notes: $*, * *, * * *$ Denote significance levels at 10,5 and $1 \%$ levels, respectively.

In the northeastern region, we reject no simultaneity at 5\% significance level for the first model and at $10 \%$ significance level for the second model. According to 2SLS estimates in the first model, wheat prices and railroad mileage have the expected signs and they are significant in explaining wheat acreage. In the second model, we see the same behaviour for wheat prices and railroad mileage. 
Table 3. Simultaneity results for corn acreage

\begin{tabular}{|c|c|c|c|c|c|c|c|}
\hline & Constant & $P^{\text {corn }}$ & $P^{\text {cattle }}$ & $P^{\text {hog }}$ & $\mathrm{RR}$ & $A_{t-1}^{\mathrm{c}}$ & Wald stat. \\
\hline \multicolumn{8}{|l|}{$\overline{\ln A_{t}^{\mathrm{c}}}$} \\
\hline \multicolumn{8}{|l|}{ Region 3} \\
\hline OLS & $0.0088 *$ & $-0.0562 * *$ & -0.0037 & 0.0233 & $0.1087 * * *$ & $0.7187 * * *$ & \multirow[t]{2}{*}{$9.24^{*}$} \\
\hline 2SLS & 0.0093 & $0.1859 * *$ & -0.0322 & $-0.1989 * *$ & $0.1667 * * *$ & $0.7450 * * *$ & \\
\hline \multicolumn{8}{|l|}{ Region 4} \\
\hline OLS & $0.0275 * * *$ & -0.0016 & $-0.0960 * *$ & 0.0376 & $0.1303^{* * *}$ & $0.7693 * * *$ & \multirow[t]{2}{*}{8.87} \\
\hline 2SLS & $0.0242 * *$ & $0.2428 * *$ & -0.0811 & -0.0964 & $0.2195^{* * *}$ & $0.7358 * * *$ & \\
\hline \multicolumn{8}{|l|}{ Region 5} \\
\hline OLS & 0.0200 & $-0.1163^{* *}$ & 0.0366 & 0.1730 & $0.0763^{* * *}$ & $0.8267 * * *$ & \multirow[t]{2}{*}{$10.94^{*}$} \\
\hline 2 SLS & 0.0128 & 0.2364 & 0.0554 & 0.0660 & $0.1137 * * *$ & $0.8316^{* * *}$ & \\
\hline
\end{tabular}

Notes: $* * *, * * *$ Denote significance levels at 10,5 and $1 \%$ levels, respectively.

However, corn prices show no significant effect. In the eastern region, Wald test statistics suggest simultaneity for both models at 5\% significance level. In both models, 2SLS gives significant and large estimates with correct signs. Similar to the northeastern region, corn prices are not significant when explaining the acreage decisions for wheat.

For the southern, mid-western and far-western regions, Wald test statistics suggest no simultaneity between prices, wheat acreage and railroad mileage. Therefore, OLS gives consistent estimates for these regions. In the southern region, both prices and railroad mileage estimates are very small and cannot explain wheat acreage. In the mid-western and far-western regions, only railroad mileage can explain the change in the acreage of wheat. Its effect is (surprisingly) negative and significant in the mid-western region. In the far-western region, on the other hand, its effect is significant and positive.

Generally speaking, these findings for western regions are consistent with Fisher and Temin's (1970) findings, but not with Harley's (1978). Fisher and Temin (1970) argued that the speed of adjustment of western farmers was slower and the reason for that could be western agricultural distress. Consumers were not willing to pay higher prices required to induce farmers to specialize completely in wheat production. However, Harley (1978) found relatively faster positive responses from farmers to wheat prices in the western region. He also found that railroad development had a significantly positive effect on farmer's wheat acreage decisions. We find this effect for northeastern, eastern and far-western states, but not for mid-western and southern states.

${ }^{8}$ For more discussions see Kirkland (1951, PP. 447-463).
Following Fisher and Temin's argument, we prefer to concentrate on western agricultural distress to examine small estimates of wheat prices and railroad mileage. We argue that the reason for these small estimates on changes in acreage of wheat may be due to the period of specialization. As we discussed before, American farmers did not specialize in specific crops immediately. Farmers knew how to cultivate soft winter wheat before 1860s. However, farmers' attempts to cultivate it during winter in Wisconsin and Minnesota were total failures. Hence, they tried to cultivate the alternative crop spring wheat, which matures late and gives a smaller yield than winter wheat. After 1860s, hard red spring wheat was introduced to the country, and cultivation spread westward. Corn, on the other hand, was an American crop and it was grown almost everywhere. It mostly served as livestock feed, and hence nearly $90 \%$ of this crop was fed to animals in this period (Kirkland, 1951). Since, both Corn Belt and Wheat Belt regions produced both small grains and livestock feed grains during the period of the study, we continue our examination of western settlement by investigating the effect of corn prices, hog and cattle prices and railroad mileage on acreage decisions for corn. Since the corn was fed mostly to animals, the centres of hog production and cattle fattening were close to the centres of corn production. ${ }^{8}$

The estimates of these relationships for the southern, mid-western and far-western states are presented in Table 3. According to the Wald statistics, there exists some simultaneity between these variables. For the south, we reject the null hypothesis of no simultaneity at $10 \%$ significance level. According to 2SLS estimates, only cattle prices do not explain the amount of acreage significantly. 
Table 4. Summary table

\begin{tabular}{|c|c|c|c|c|c|c|c|c|}
\hline & & $A^{\text {wheat }}$ & $A^{\text {corn }}$ & $P^{\text {wheat }}$ & $P^{\text {corn }}$ & $P^{\text {cattle }}$ & $P^{\text {hog }}$ & $\mathbf{R R}$ \\
\hline United States & $\begin{array}{l}\text { Model } 1 \\
\text { Model } 2\end{array}$ & $\begin{array}{l}+ \\
+\end{array}$ & & $\begin{array}{l}+ \\
+\end{array}$ & - & & & $\begin{array}{l}+ \\
+\end{array}$ \\
\hline Regions & & & & & & & & \\
\hline Northeastern states & $\begin{array}{l}\text { Model } 1 \\
\text { Model } 2\end{array}$ & $\begin{array}{l}+ \\
+\end{array}$ & & $\begin{array}{l}+ \\
+\end{array}$ & .. & & & $\begin{array}{l}+ \\
+\end{array}$ \\
\hline Eastern states & $\begin{array}{l}\text { Model } 1 \\
\text { Model } 2\end{array}$ & $\begin{array}{l}+ \\
+\end{array}$ & & $\begin{array}{l}+ \\
+\end{array}$ & .. & & & $\begin{array}{l}+ \\
+\end{array}$ \\
\hline Southern states & $\begin{array}{l}\text { Model } 1 \\
\text { Model } 2 \\
\text { Model } 3\end{array}$ & $\begin{array}{l}+ \\
+\end{array}$ & + & $\begin{array}{l}. . \\
. .\end{array}$ & $\begin{array}{l}. . \\
+\end{array}$ & .. & - & $\begin{array}{l}. . \\
. . \\
+\end{array}$ \\
\hline Western states & $\begin{array}{l}\text { Model } 1 \\
\text { Model } 2 \\
\text { Model } 3\end{array}$ & $\begin{array}{l}+ \\
+\end{array}$ & + & $\begin{array}{l}. . \\
. .\end{array}$ & $\begin{array}{l}. . \\
+\end{array}$ & .. & .. & $\begin{array}{l}- \\
- \\
+\end{array}$ \\
\hline Far-western states & $\begin{array}{l}\text { Model } 1 \\
\text { Model } 2 \\
\text { Model } 3\end{array}$ & $\begin{array}{l}+ \\
+\end{array}$ & + & $\begin{array}{l}. . \\
. .\end{array}$ & $\begin{array}{l}. . \\
. .\end{array}$ & .. & .. & $\begin{array}{l}+ \\
+ \\
+\end{array}$ \\
\hline
\end{tabular}

Notes: $A^{\text {wheat }}$ and $A^{\text {corn }}$ state for acreage of wheat and corn, respectively; $P$ stands for prices and RR stands for railroad mileage.

Blank left values state for variables not included in the model. '..' States that the corresponding variable was included into the model but it did not significantly affect the model.

Model 1: $\log A_{i t}^{\mathrm{W}}=\alpha+\beta \log P_{i t}^{\mathrm{W}}+\mu \log A_{i t-1}^{\mathrm{W}}+\rho \log \mathrm{RR}_{i t}+\varepsilon_{i t}$.

Model 2: $\log A_{i t}^{\mathrm{w}}=\alpha+\beta \log P_{i t}^{\mathrm{w}}+\gamma \log P_{i t}^{\mathrm{c}}+\mu \log A_{i t-1}^{\mathrm{w}}+\rho \log \mathrm{RR}_{i t}+\varepsilon_{i t}$.

Model 3: $\log A_{i t}^{\mathrm{c}}=\alpha+\beta \log P_{i t}^{\mathrm{c}}+\gamma \log P_{i t}^{\mathrm{c} a t t l e}+\varphi \log P_{i t}^{\mathrm{h} o g}+\mu \log A_{i t-1}^{\mathrm{c}}+\rho \log \mathrm{RR}_{i t}+\varepsilon_{i t}$.

All the other estimates are statistically significant and have the expected signs. For the mid-western region, we do not reject the null hypothesis of no simultaneity and according to the OLS estimates cattle prices and railroad mileage are statistically significant and have expected signs. In the far west, we reject the null hypothesis at $10 \%$ significance level. Only railroad mileage appears to explain the model in this region significantly. The summary of all the findings that show the interaction between our model variables are presented in Table 4.

\section{Concluding Remarks}

Some economists have failed in their attempts to find a role for prices in the western expansion process. While Harley (1978) explained the failure with no attention to spatial distribution of prices in these studies, this study offered a different approach by modelling prices and railroad development endogenously.

Our results indicated that wheat prices and railroad development played an important role in explaining the wheat acreage decisions in northeastern and eastern states when wheat and corn prices were treated endogenously. Nevertheless, we also found that wheat prices were not significant in explaining the changes in wheat acreage in the western expansion. On the other hand, corn and cattle prices played an important role in the expansion of settlement in the mid-western and southern states.

We can suggest some explanations for our findings which may be a scope of future research. First, during the period of the study eastern states were settled and had well-defined and integrated markets. Therefore, farmers were likely to be more sensitive to price changes. However, western states were still being settled in at the beginning of the period. Although it was relatively easy to obtain title for farmland, settlement was not a very easy process. Agriculture had to make a readjustment through irrigation, dry farming and through new crops. It was very difficult for farmers to anticipate their costs accurately. It was more likely that they adapted their techniques over time, as they understood their costs and benefits from cultivation. Profits depended on farmers' knowledge of soils, crop varieties, and cultivation methods. In the 1860 s, farmers were probably more risk averse, and so they chose traditional products such as corn, hogs, and cattle crop mix. In 1880, in contrast to the 1860 s, farmers focused more on the effects of soil variability and mobility on their choice of crops. Thus, farmers may have responded more to corn prices in their corn acreage decisions than to wheat prices in their wheat acreage decisions. 
Second, the labour force on farms was associated with the soil type (Gregson, 1993). If the soil was diverse, farmers harvested grains, and if the soil was homogenous, farmers used their labour in cornfields. Additionally, structural changes in this period induced farmers to substitute agricultural production for leisure (Craig and Weiss, 2000). Therefore, even though the corn, hogs and cattle crop mix required more labour, farmers' decisions might not have aimed towards small grains as average hours worked also increased. This leaves the soil type to be a more important determinant in farmers' crop choices.

It is also worth looking into the impact of labour availability on crop choices during this period. An increase in acreage meant more labour required in the examined period, and this therefore placed a constraint on crop choices and the number of acres actually sown. Gregson (1993), for example, showed that larger quantities of household labour were associated with crop mixes that were less concentrated on small grains and more concentrated on corn, hogs and cattle.

\section{References}

Atack, J. and Passell, P. (1994) A New Economic View of American History: From Colonial Times to 1940, 2nd ed., W. W. Norton \& Company.

Bogue, A. G. (1963) From Praire to Corn Belt, University of Chicago Press, Chicago.

Cooley, T. F. and DeCanio, S. J. (1977) Rational expectations in American agriculture, 1867-1914, The Review of Economics and Statistics, 59, 9-17.
Craig, L. and Weiss, T. (2000) Hours at work and total factor productivity growth in nineteenth century US Agriculture, Advances in Agricultural Economic History, 1, 1-30.

Fisher, F. M. and Temin, P. (1970) Regional specialization and the supply of wheat in the United States, 1867-1914, Review of Economics and Statistics, 52, 134-49.

Fishlow, A. (1965) American Railroads and the Transformation of the Anti Bellum Economy, Harvard University Press, Cambridge, MA.

Gregson, M. E. (1993) Rural response to increased demand: crop choice in the midwest, 1860-1880, Journal of Economic History, 53, 332-45.

Guven Solakoglu, E. and Goodwin, B. K. (2005) The effects of railroad development on price convergence among the states of the USA from 1866 to 1906, Applied Economics, 37, 1747-61.

Harley, C. K. (1978) Western settlement and the price of wheat, 1872-1913, Journal of Economic History, 38, 865-78.

Kennedy, P. (1992) A Guide to Econometrics, 3rd ed., MIT Press, Cambridge.

Kirkland, E. C. (1951) A history of American Economic Life, 3rd ed., Appleton-Century-Crafts, Inc., New York.

Malenbaum, W. (1953) The World Wheat Economy, 1885-1939, Harvard University Press, Cambridge, MA.

Poor, H. V. (1988), Manual of Railroads of the United States, manuals 1873-74, 1881, 1888.

U.S. Department of Agriculture (1907) Corn Crops of the United States, 1866-1906, Bureau of Statistics, Bulletin 56.

U.S. Department of Agriculture (1908) Wheat Crops of the United States, 1866-1906, Bureau of Statistics, Bulletin 56.

U.S. Department of Agriculture (1907) Number and Farm Value of Farm Animals in the United States, 1867-1906, Bureau of Statistics, Bulletin 64. 